\title{
Studi Perencanaan Pondasi Sumuran Pada Pembangunan Gedung Bertingkat Tinggi (Perbandingan Antara Pondasi Tiang Pancang dan Pondasi Sumuran)
}

\author{
Soaloon Prima SIMALANGO ${ }^{1}$, Agus PURBA ${ }^{1}$, Kasimir SAWITO $^{1 *}$ \\ ${ }^{1}$ Program Studi Teknik Sipil, Fakultas Teknik, Universitas Mpu Tantular, \\ email : kasimirsawito@gmail.com
}

Sejarah artikel Diserahkan: Dalam bentuk revisi: 6 April 2021

\author{
Diterima: \\ 30 Mei 2021 \\ Tersedia online: $\quad 31$ Mei 2021
}

\begin{abstract}
This study aims to provide a description of an alternative design of the foundation structure using the caisson foundation structure. The method used in this research is literature study, in which series of data were collected from various references, combined with building technical data collection, and also direct site survey. It was found that the load < bearing capacity of the foundation, and therefore the caisson structure was applicable. Foundation Type 1 is known to be $Q a=313.323$ tonnes $>P u=$ 245.071 tonnes. Type 2 is known to be $Q a=200.363$ tonnes $>P u=125.424$ tonnes. And Type 3 is known to be $Q a=200.735$ tonnes $>P u=19.296$ tonnes. For pile cap reinforcement, it was calculated D19-200 for tensile reinforcement, and D10-250 for compressive reinforcement, whereas for spiral reinforcement and principal reinforcement use $\emptyset 10-50$ and 28 D 25, respectively. Foundation type 1 is used for the caisson foundation reinforcement. As per calculation, principal reinforcement, distance between principal reinforcement, foundation diameter, spiral reinforcem ent diameter, number of principal reinforcement and distance of spiral reinforcement use one type of diameter, 1 meter.
\end{abstract}

Keywords: caisson, soil bearing capacity, reinforcement, settlement

\begin{abstract}
Abstrak
Penelitian ini bertujuan untuk memberi sebuah deskripsi alternatif perencanaan struktur pondasi memakai struktur pondasi sumuran. Penelitian ini menggunakan metode studi literatur yang mana bermaksud menghimpun data dari beberapa sumber referensi, dilanjutkan dengan menghimpun data teknis gedung, serta survei langsung untuk melihat keadaan lapangan. Diperoleh bahwa beban yang harus ditahan < daya dukung pondasi sumuran, sehingga pondasi sumuran sesuai penggunaan. Tipe 1 diketahui $Q a=313,323$ ton $>P u=245,071$ ton, tipe 2 diketahui $Q a=200,363$ ton $>P u=125,424$ ton, dan tipe 3 diketahui $Q a=200,735$ ton $>P u=19,296$ ton. Terhadap hitungan penulangan pile cap pada tulangan tarik memakai tulangan D19 - 200 dan tulangan tekan memakai tulangan D10 250, adapun sumuran memakai tulangan spiral $\emptyset 10-50$ dan tulangan pokok 28 D 25. Tipe pondasi 1 dipakai pada penulangan pondasi sumuran. Sesuai hasil perhitungan, dipakai tulangan pokok, diameter pondasi, jarak antar tulangan pokok, diameter tulangan spiral, jumlah tulangan pokok dan jarak tulangan spiral satu tipe yakni diameter 1 meter. Pada tulangan spiral $\emptyset 10-50$ dan tulangan pokok 28 D 25. Ini disebabkan pendistribusian tegangan beban yang harus diterima tiang sumuran dari hasil perhitungan jika dilakukan perencanaan tulangan dan dimensi sama, sesuai penggunaan.
\end{abstract}

Kata kunci: daya dukung tanah, sumuran, penulangan, penurunan

\section{Pendahuluan}

Pertumbuhan dan perkembangan penduduk sangat pesat menuntut disediakannya hunian yang layak hingga prasarana dan fasilitas umum. Berbagai sarana tersebut diantaranya jalan, rumah 
tempat tinggal, kantor, rumah sakit, pusat perbelanjaan dan lainnya. Selain itu, perkembangan ilmu pengetahuan dan teknologi menuntut berbagai perkembangan pada penggunaan alternatif desain struktur yang disesuaikan fungsinya. Hal tersebut mendorong tenaga ahli perencanaan, pelaksana hingga pengawas pembangunan dalam mengimplementasikan dan mendalami berbagai konsep teknologi. Khususnya pada pembangunan struktur pondasi.

Pondasi ialah salah satu kontruksi sebagai penghubung dalam sebuah struktur dengan tanah, sedangkan tanah ialah penopangnya. Dalam pembanguna sebuah struktur bangunan dibutuhkan perencanaan pondasi yang dapat menyambungkan antara tanah dengan sebuah struktur bangunan dengan tepat. Sementara itu, dalam pemilihan pondasi harus dapat disesuaikan dengan struktur tanah, sehingga pondasi tersebut akan terjadi kecocokan dalam berbagai jenis kondisi alam. Biasanya pondasi terdapat dua macam, antara lain pondasi dangkal dimana di dalamnya termasuk dalam pondasi rakit dan telapak. Sedangkan, pondasi dalam terdapat tiang bor, pondasi strauss, pondasi sumuran dan tiang pancang. Pada penelitian ini penulis berkeinginan untuk melakukan perencanaan pemakaian pondasi sumuran di proyek pada pembanguna gedung bertingkat tinggi (Tomlinson, 2014; Pamungkas, 2013; Bowles, 1996).

Sesuai dengan latar belakang masalah dan batasan lingkup pembahasan sebagaimana dikemukana, rumusan masalah ini memiliki tujuan untuk memberi sebuah deskripsi ataupun alternatif perencanaan struktur pondasi memakai struktur pondasi sumuran. Sehingga manfaat pelaksanaan penelitian ini yaitu bisa melakukan perencanaan struktur pondasi secara tepat sesuai data tanah, dengan demikian memperoleh hasil sesuai analisis data.

\section{Pengertian Pondasi}

Dalam ilmu teknik sipil pondasi bisa diartikan sebuah lapisan tanah padat (keras) atau struktur yang memilki daya dukung kuat serta memiliki fungsi sebagai penghubung beban menuju lapisan tanah dibawahnya, sehingga pondasi sudah sangat jelas begitu penting dalam sistem perekayasaan yang seharusnya dapat adanya jaminan keseimbangan bangunan pada beban (Rahardjo, 2005; Hardiyatmo, 1996; 2008).

Hal harus diperhatikan apakah pondasi tersebut tepat terhadap kondisi tanah di lapangan serta dapatkan pondasi tersebut bisa selesai dikerjakan tepat waktu, merupakan cara memilih pondasi yang memadai. Dalam menetapkan penggunaan tipe pondasi, terdapat sejumlah faktor sebagai pertimbangan, yaitu : (Sardjono, 1991)

a. Kondisi tanah dasar dimana bangunan akan dibangun

b. Beratnya bangunan dan besarnya beban atas yang bekerja

c. Fungsi bangunan atas

d. Waktu dan biaya pekerjaan

Untuk merencanakan pondasi, dalam mencegah gagalnya fungsi pondasi jadi pondasi harus dirancang sesuai dengan kondisi tanah yang aman, dan mampu memberi dukung beban bangunan tanpa muncul degradasi secara berlebih. Dalam melihat kedalaman atau letak lapisan tanah yang keras dengan daya dukung yang cukup kuat, jadi butuh dilaksanakan observasi tanah terlebih dahulu (Tomlinson, 2014; Pamungkas, 2013; Bowles, 1996).

\section{Pondasi Sumuran}

Pada teknik pondasi kata sumuran memiliki arti duan tidak sama isinya. Sesuai pemakaian yang pertama, sumuran ialah suatu struktur bagian tanah bawah melayani pemakaian yang sama seperti telapak, ialah untuk melanjutkan beban ke lapisan yang dapat mendorongnya sehingga tidak menimbulkan degradasi atau runtuhan yang cukup signifikan. Akan tetapi terdapat ketidaksamaan dengan telapak, ialah, rasio lebar alas sumuran > 4 terhadap kedalaman pondasi, semantara itu untuk telapak, rasio tersebut biasanya kurang dari satu.

Sesuai pemakaian kedua, sumuran yaitu pendukung, umumnya dari pasangan baru ataupun beton, untuk struktur atas jembatan. Sumuran umumnya timbul pada tanah permukaan atas, 
serta biasanya timbul sampai di atas air sampai pada sebuah ketinggian di atas air maksimum. Jadi, sebuah sumuran bisa dikatakan sebagai sebuah struktur di dalam dirinya sendiri. Dalam mencegah rancunya, sehingga definisi tiang sumuran dapat dipakai dalam mendefinisikan bagian di atas pondasi. Dalam teknik di atas bisa di lakukan menggunakan 2 teknik antara lain:

A. Dengan cara penggalian sampai pada dalamnya pondasi serta sumuran terbuat pada lubang dalam itu. Apabila tanah bisa dibelah tegak tidak adanya gangguan keseimbangannya sehingga keadaan sumuran ini bisa dikerjakan tidak pakai casing, namun keadaan terbalik artinya butuh casing.

a. Tanpa casing

Melaksankan dengan dilakukan penggalian lubang contohnya sumuran hingga lapisan yang sudah dirancang menggunakan SDM. Selanjutnya pengisian pada lubang menggunakan material sesuai rencana, beton cyclop.

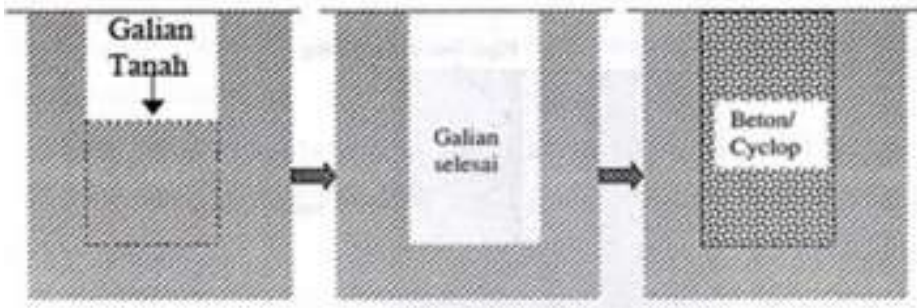

Gambar 1. Proses pondasi sumuran tanpa casing

b. Dengan casing yang diambil

Dilaksanakan menggali dengan beberapa tahap, ialah casing diturunkan secukupnya selanjutnya penggalian tanah di dalam casing, selanjutya penurunan casing secukupnya kemudian penggalian lagi tanah pada penurunan casing, dengan tahapan seperti seterusnya hingga sampai pada kedalaman yang diharapka. Setelah itu dilaksanakan dengan lubang diisi memakai beton atau cyclop selanjutnya menarik casing ke atas. Seperti itu secara berulang sampai casing ke luar lagi dari lubang.

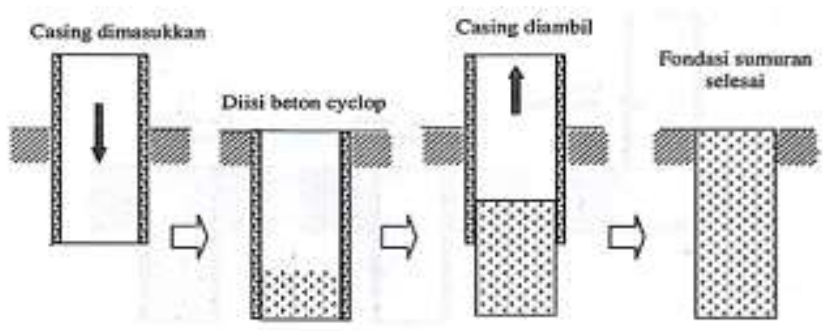

Gambar 2. Proses pondasi sumuran dengan cassing diambil

c. Dengan casing yang ditinggal

Biasanya casing dibuat dari beton buis, maka casing tersebut memiliki fungsi untuk bagian struktur. Penurunan beton buis melalui teknik penggalian tanah di buis, serta penurunan beton buisnya sampai dengan elevasi yang ditentukan, dengan berbagai tahapan. selanjutaya lubang diisi dengan material yang telah ditentukan, contohnya beton cyclop. Pelaksanaan prose pada jenis pondasi tersebut kadang harus berhadapan dengan air tanah. 


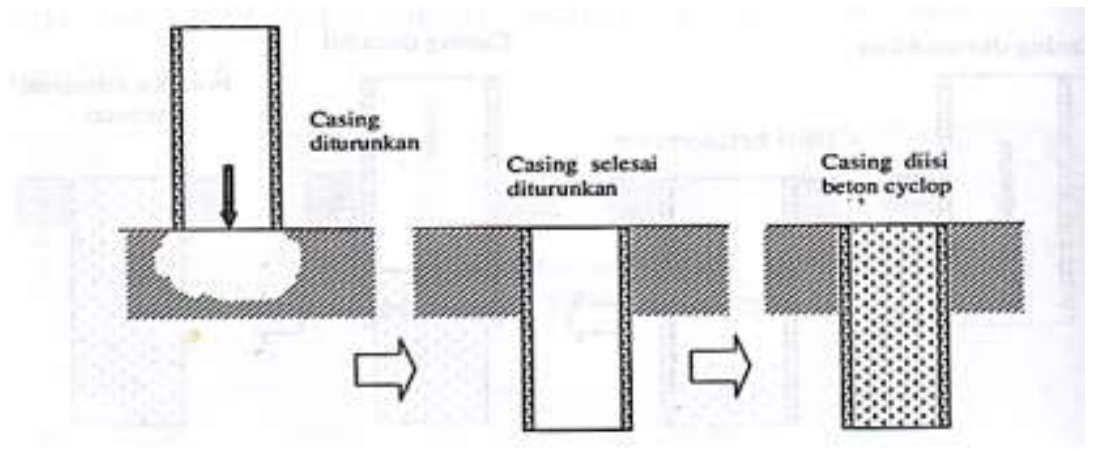

Gambar 3. Proses pondasi sumuran dengan cassing ditinggal

B. Pemakaian caisson, yaitu suatu kotak yang dibenamkan sampai letak yang diharapkan, selanjutnya ialah bagian luar sumuran. Umumnya dalam pondasi sumuran dalam air. Cara tersebut disebut dengan teknik udara tertekan yang kemungkinan membersihkan semua gangguan di bawah pinggiran caisson dan mempermudah membersihkan bagian bawah galian.

C. Pemakaian teknik tersebut memiliki dampak serta berbahaya untuk kesehatan pekerja, sebab sebaik hal tersebut untuk tidak dilakukan.

Kelebihan yang bisa didapatkan melalui penggunaan tiang sumuran yaitu :

$\checkmark$ Sangat tepat untuk yang bekerja di wilayah masyarakatnya padat sebab tidak ada getaran.

$\checkmark$ Bisa dibuat tiang lurus berdiameter besar serta untuk tiang panjang bisa dijalankan secara mudah, sebab tanpa sambungan.

$\checkmark$ Biasanya diameter $>$ tiang pracetak sertan daya dukung masing-masing tiang juga sangat besar maka tumpuan bisa diatur lebih rendah.

$\checkmark$ Untuk bangunan di dekatnya pengaruhnya kecil.

$\checkmark$ Dapat divariasikan kedalaman tiang.

$\checkmark$ Memeriksa tanah serta mencocokan sesuai data laboratorium.

$\checkmark$ Pemasangan tiang hingga kedalaman yang sudah dirancang, berdiameter besar serta pada ujung bawah bisa dilaksanakan pembesaran apabila dasar tanah yaitu batu lunak atau lempung.

Ada juga kekurangan serta resiko yang didapatkan jika memakai penggunaan tiang sumuran antara lain :

- Beberapa perihal, tubuh tiang (beton) yang ada pada bawah air mutunya sesudah selesai lebih rendah daripada tiang pracetak. Selain itu, pengecekan pada mutu hanya bisa dilaksankan dengan tidak langsung.

- Apabila dituangkannya beton, adukan beton akan bercampur dengan runtuhan tanah akan kurang maksimal. Maka dari itu, sesudah melakukan penggalian, dituangkan beton harus secara seksama.

- Meskipun penetrasi menuju ke tanah pendukung pondasi sudah tercukupi terkadang terjadi bahwa tiang pendukung tidak sempurna sebab tercampurnya timbunan lumpur di dasar.

- Membutuhkan beberapa beton sehingga biaya yang dibutuhkan jaga cukup besar sebab diameter tiang besar.

- Air tanah bisa mengurangi mutu beton tersebut karena dapat mempengaruhi pengecoran beton.

- Ujung bawah tiang tidak bisa dilaksanakan pembesaran apabila tanah berbentuk pasir. 


\section{Metodologi}

Penelitian ini secara garis besar dilakukan dengan memakai tahapan sebagai berikut.

(a) Penghimpunan semua data dalam menganalisis :

- Peta topografi.

- Data observasi tanah.

- Analisis konstruksi gedung.

(b) Penghimpunan semua data perencanaan.

(c) Mengolah data perencanaan pondasi.

Untuk pengumpulan data, penelitian ini memakai metode penelitian literatur, yang mana studi literatur bermaksud mengumpulkan data dari berbagai sumber referensi yang berhubungan dengan pondasi dan topik penelitian yang dikaji. Selain itu, data juga dikumpulkan melalui observasi dan menghimpun semua data teknis gedung, serta dengan melakukan survei langsung ke lokasi proyek. Survei ini bertujuan untuk melihat keadaan lapangan objek penelitian.

\section{Hasil dan Pembahasan}

\section{Data Perencanaan}

Spesifikasi Umum,

- Fungsi Bangunan : Gedung Apartement

- Struktur Atap : Beton bertulang

- Struktur Bawah : Pondasi Sumuran

- Lantai Bangunan : Plat beton bertulang

Parameter perencanaan,

- Peraturan Perencanaan Dasar : SNI 03-1726-2002 (“Standar Perencanaan Ketahanan Gempa Untuk Bangunan); SNI 03-2847-2002 ("Tata Cara Perhitungan Beton Bertulang"); PPIUG 1983 ("Peraturan Pembebanan Indonesia Untuk Gedung") .

- Kuat Tekan Beton (f'c) : $\quad 30 \mathrm{Mpa} \& 18 \mathrm{Mpa}$

- Tegangan Leleh Tulangan (fy) : $400 \mathrm{Mpa}$

\section{Parameter Tanah}

a. Sesuai klasifikasi tanah, diperoleh jenis tanah ialah pasir berlanau. "konversi nilai sondir ke data SPT qc = 4 N" (Hardiyatmo, H.C : 234) dimana, $\mathrm{N}=$ nilai SPT, dan qc = tahanan konus $(\mathrm{kg} / \mathrm{cm} 2)$ "

b. Syarat dari daya dukung (Qijin) dapat diperhitungkan melalui : $\mathrm{Q}_{\mathrm{ijin}}=\frac{Q u}{2,5}$

Nilai 2,5 ialah faktor keamanan terhdap gesekan selimut ataupun daya dukung ujung tiang sumuran. $\mathrm{Qu}=$ akibat daya dukung ultimate tiang

c. Apabila daya dukung tidak mencukupi dalam penerimaan beban dari atas sehingga penambahan kedalaman tiang (konfigurasi tiang).

\section{Perencanaan Pondasi Sumuran}

Sesuai output analisis pembebanan melalui Staad Pro mengambil 3 contoh tipe untuk merencanakan pondasi dengan gaya terhadap setiap tipe bisa diamati dari tabel berikut:

Tabel 1 Analisis pembebanan terhadap setiap tipe pondasi

\begin{tabular}{|c|c|c|c|c|c|c|c|}
\hline $\begin{array}{c}\text { Tipe } \\
\text { Pondasi }\end{array}$ & NODE & $\begin{array}{c}\text { Fy } \\
(\mathbf{k g})\end{array}$ & $\begin{array}{c}\text { Fz } \\
(\mathbf{k g})\end{array}$ & $\begin{array}{c}\mathbf{F x} \\
(\mathbf{k g})\end{array}$ & $\mathbf{M x ~ ( k g )}$ & $\begin{array}{c}\text { My } \\
(\mathbf{k g})\end{array}$ & $\mathbf{M z}(\mathbf{k g})$ \\
\hline Berat & 9, KOM 2 & 235000 & 1370 & 70849 & 12963 & 424 & -1593 \\
\hline Sedang & 4, KOM 6 & 118000 & 7420 & 1710 & 165549 & 901 & -37257 \\
\hline Ringan & 22, KOM 6 & 12800 & 9720 & 3460 & 212683 & 3278 & -66247 \\
\hline
\end{tabular}




\section{Bentuk Penampang Pondasi Dengan Beban Berat ( Tipe 1 )}

Penampang pondasi berbentuk dengan beban berat (Tipe 1) dengan beban maksimum 235 ton dari hasil input STAAD Pro 3D kemudian dirancang pondasi sumuran antara lain :
a. Panjang pondasi sumuran (Df)
$=290 \mathrm{~cm}$
$=2,9 \mathrm{~m}$
b. Kedalaman sumuran
$=340 \mathrm{~cm} \quad=3,4 \mathrm{~m}$
c. Tebal selimut poer direncanakan
$=50 \mathrm{~cm}$
$=0,5 \mathrm{~m}$
d. Diameter luar $\left(\mathrm{B}_{\text {luar }}\right)$
$=100 \mathrm{~cm}$
$=1,0 \mathrm{~m}$
e. Diameter dalam $\left(\mathrm{B}_{\text {dalam }}\right)$
$=65 \mathrm{~cm}$
$=0,65 \mathrm{~m}$
f. Luas penampang (A) tiang
$=\left(1 / 4 * \pi * 1,0^{2}\right)$
$=0,785 \mathrm{~m}^{2} 7$.
g. Luas selimut tiang (As)
$=(2 * \pi * 0,5 * 2,9) \quad=9,106 \mathrm{~m}^{2}$
h. Berat pile cap $=\mathrm{p}^{* 1 * t * b j b . b e r t u l a n g}=(2,0 * 2,0 * 0,5 * 2,4)=4,8$ ton

Daya dukung pondasi sumuran kelompok Tipe 1

Berdasarkan daya dukung bahan,

$\mathrm{Qd}=\sigma_{\text {bahan }} \times \mathrm{A}_{\text {tiang }}$

Keterangan : $\sigma_{\text {bahan }}=$ tegangan ijin bahan

$\mathrm{A}_{\text {tiang }}=$ luas penampang tiang pondasi sumuran

- Untuk dinding sumuran ( $\left(\mathrm{fc}^{\prime}: 30 \mathrm{Mpa}\right)$

$$
\begin{aligned}
\mathrm{Qd}_{1}=(0,85 * \mathrm{fc} ') *\left(\left(1 / 4 * \pi * \mathrm{D}_{2}\right)-\left(1 / 4 * \pi * \mathrm{D}_{\text {dalam } 2}\right)\right) \\
=(0,85 * 300) *\left(\left(1 / 4 * \pi^{*} 1002\right)(1 / 4 * \pi * 652)\right) \\
=1156010 \mathrm{~kg}=1156,01 \text { ton }
\end{aligned}
$$

- Untuk beton cyclop (fc' : $18 \mathrm{Mpa})$

$$
\begin{aligned}
\mathrm{Qd}_{2} & =\left(0,85^{*} \mathrm{fc}^{\prime}\right) *\left(1 / 4 * \pi^{*} \mathrm{D}_{\text {dalam } 2}\right) \\
& =(0,85 * 180) *\left(1 / 4 * \pi^{*} 652\right) \\
& =507443 \mathrm{~kg}=507,443 \text { ton }
\end{aligned}
$$

Maka, daya dukung atas dasar kekuatan bahan dapat dihitung sebagai berikut.

$$
\begin{aligned}
\mathrm{Qd}_{\text {bahan }} & =\mathrm{Qd}_{1}+\mathrm{Qd}_{2} \\
& =1156,01+507,443 \\
& =1663,454 \text { ton }
\end{aligned}
$$

Berdasarkan hasil analisis struktur melalui program STAAD Pro 3D, diperoleh :

$\sum \mathrm{Vu}=$ Beban bangunan atas (beban vertikal) $+\mathrm{Wp}+$ Berat pile cap

$\mathrm{n}$

$$
=235+5,271+4,8 \quad=245,071 \text { ton }
$$

$=\Sigma \mathrm{Vu} / \mathrm{Qa}$

$$
=245,71 / 313,323 \quad=0,785 \approx 1 \text { buah }
$$

$\mathrm{Pu}=\sum \mathrm{V}+$ berat sendiri tiang + berat pile cap dimana,

$$
\begin{aligned}
\mathrm{P}_{1} & =\left(\left(1 / 4 * \pi * \mathrm{D}_{2}\right)-\left(1 / 4 * \pi * \mathrm{D}_{\text {dalam2 }}\right)\right) * \mathrm{Df} * \lambda_{\text {beton bertulang }} * \text { jumlah tiang } \\
& =((1 / 4 * 3,14 * 1,02)-(1 / 4 * 3,14 * 0,652)) * 2,9 * 2,4 * 1 \\
& =3,155 \text { ton }
\end{aligned}
$$

Total berat sendiri sumuran: $\mathrm{P}_{\text {tiang }} \quad=\mathrm{P}_{1}+\mathrm{P}_{2}$

$$
\begin{aligned}
& =3,155+2,12 \\
& =5,271 \text { ton }
\end{aligned}
$$

$\mathrm{Pu}=\sum \mathrm{V}+$ berat sendiri tiang + berat pile cap

$=235+5,271+4,8$

$=245,071$ ton $<\mathrm{Qa}(313,323$ ton $) \quad \rightarrow$ (syarat aman $)$

$\underline{\text { Penurunan untuk pondasi sumuran kelompok Tipe } 1}$

Penurunan akibat deformasi aksial tiang tunggal (S1)

$$
\begin{aligned}
\mathrm{S} 1 & =((\mathrm{Qwp}+\mathrm{a} * \mathrm{Qws}) * \mathrm{~L}) /(\mathrm{Ap} * \mathrm{Ep}) \\
& =((5,271+0,5 * 9,106) * 2,9) /(0,785 * 25000)=0,00145 \mathrm{~m}
\end{aligned}
$$




\section{Bentuk Penampang Pondasi Dengan Beban Berat ( Tipe 2)}

Penampang pondasi berbentuk dengan beban berat (Tipe 2) dengan beban maksimum 118 ton dari hasil input STAAD Pro 3D kemudian dirancang pondasi sumuran sebagai berikut :
a. Panjang pondasi sumuran (Df)
$=290 \mathrm{~cm}$
$=2,9 \mathrm{~m}$
b. Kedalaman sumuran
$=340 \mathrm{~cm} \quad=3,4 \mathrm{~m}$
c. Tebal selimut poer direncanakan
$=50 \mathrm{~cm}$
$=0,5 \mathrm{~m}$
d. Diameter luar $\left(\mathrm{B}_{\text {luar }}\right)$
$=90 \mathrm{~cm}$
$=0,9 \mathrm{~m}$
e. Diameter dalam $\left(\mathrm{B}_{\text {dalam }}\right)$
$=40 \mathrm{~cm}$
$=0,4 \mathrm{~m}$
f. Luas penampang (A) tiang
$=\left(1 / 4 * \pi * 0,8^{2}\right) \quad=0,5024 \mathrm{~m}^{2}$
g. Luas selimut tiang (As)
$=(2 * \pi * 0,4 * 2,9) \quad=7,284 \mathrm{~m}^{2}$
h. Berat pile cap $=\mathrm{p}^{*} \mathbf{1}^{*}$ t bjb.bertulang $=(1,6 * 1,6 * 0,5 * 2,4)=3,072$ ton
Qws = beban yang dikarenakan gesekan selimut pondasi
Ap = luas penampang tiang
$\mathrm{L} \quad=$ panjang tiang
Ep = modulus elatisitas tanah (pasir berlempung)
$\alpha=$ koef. Yang bergantung pada distribusi gesekan selimut pada pondasi. Seragam atau parabola murni, nilai $\alpha$ adalah setara dengan 0,5

\section{Daya dukung pondasi sumuran kelompok Tipe 2}

Berdasarkan hasil analisis struktur melalui program STAAD Pro 3D, diperoleh :

$$
\begin{aligned}
\sum \mathrm{Vu} & =\text { Beban bangunan atas (beban vertikal) }+\mathrm{Wp}+\text { Berat pile cap } \\
& =118+4,352+3,072 \\
& =125,424 \text { ton } \\
& =\Sigma \mathrm{Vu} / \mathrm{Qa} \\
& =125,424 / 200,678 \\
& =0,625 \approx 1 \text { buah }
\end{aligned}
$$

\section{Bentuk Penampang Pondasi Dengan Beban Berat ( Tipe 3 )}

Penampang pondasi berbentuk dengan beban berat (Tipe 3) dengan beban maksimum 12,8 ton dari hasil input STAAD Pro 3D kemudian dirancang pondasi sumuran sebagai berikut :
a. Panjang pondasi sumuran (Df)
$=290 \mathrm{~cm} \quad=2,9 \mathrm{~m}$
b. Kedalaman sumuran
$=340 \mathrm{~cm} \quad=3,4 \mathrm{~m}$
c. Tebal selimut poer direncanakan
$=50 \mathrm{~cm} \quad=0,5 \mathrm{~m}$
d. Diameter luar (B $\left.B_{\text {luar }}\right)$
$=80 \mathrm{~cm} \quad=0,8 \mathrm{~m}$
e. Diameter dalam ( $\left.\mathrm{B}_{\text {dalam }}\right)$
$=40 \mathrm{~cm}$
$=0,4 \mathrm{~m}$
f. Luas penampang (A) tiang
$=\left(1 / 4 * \pi * 0,8^{2}\right) \quad=0,5024 \mathrm{~m}^{2}$
g. Luas selimut tiang (As)
$=(2 * \pi * 0,4 * 2,9) \quad=7,284 \mathrm{~m}^{2}$
h. Berat pile cap $=\mathrm{p} * 1 * t *$ bjb.bertulang $=(1,6 * 1,6 * 0,5 * 2,4)=3,072$ ton

Daya dukung pondasi sumuran kelompok Tipe 3

Berdasarkan hasil analisis struktur melalui "program STAAD Pro 3D, didapatkan :

$\sum \mathrm{Vu}=$ Berat pile cap + Beban bangunan atas (beban vertikal) $+\mathrm{Wp}$

$=3,072+12,8+3,424$

$=19,296$ ton

$\underline{\text { Penurunan untuk pondasi sumuran kelompok Tipe } 3}$

Terhadap estimasi besaran penurunan pondasi tiang tunggal, deformasi tiang batang bisa dievaluasi memakai prinsip dasar mekanik bahan dimana pondasi sumuran yang menerima gaya eksentrisitas. Dalam menghitung penulangan tiang pondasi sumuran dan pile cap, tipe pondasi 1 yang diambil dalam perencanaan menggunakan perhitungan penulangan dengan beban berat. Dikarenakan hanya ada 1 tiang pondasi, sehingga momen arah X diakibatkan reaksi tiang sumuran $=0$. Dengan demikian : 


$$
\begin{array}{ll}
\mathrm{P} & =235 \text { ton } \\
(\mathrm{Y} / \mathrm{L})_{1} & =0 /(0+0)=0 \\
\mathrm{Mxe} & =0,32
\end{array}
$$

\section{Penulangan Poer Pondasi Sumuran}

\section{Penulangan poer arah Z}

Berdasarkan SK-SNI T-15-1991, syarat rasio baja tulangan adalah $\rho_{\text {min }} \leq \rho$ ada $\leq \rho_{\text {maks }}$.

- Apabila $\rho_{\text {ada }}>\rho_{\max }$, sehingga harus memperbesar tinggi poer

- Apabila $\rho_{\text {ada }}>\rho_{\text {min }}$, sehingga dipakai $\rho_{\text {ada }} \sim \rho_{\min } \&$ As $=\rho_{\text {ada }} * b * d$

Sehingga memenuhi syarat no. 1, digunakan $\rho_{\min } \sim \rho_{\text {ada }}=0,004$ dan dimensi poer memenuhi untuk digunakan. Perencanaan tulangan tekan memakai D10, dan penggunaan tulangan pokok $($ bawah $/$ tarik $)=\mathrm{D} 19-200 \mathrm{~mm}$.

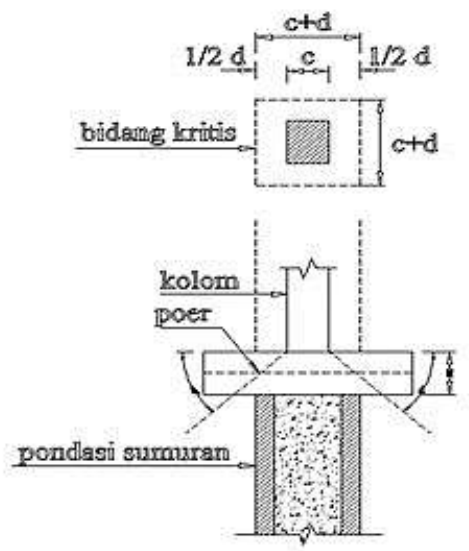

Gambar 4. Skema geser pons terhadap kolom

\section{Perencanaan Penulangan Pondasi Sumuran}

Menghitung pondasi tiang sumuran sesuai dengan menghitung kolom bulat.

Data perencanaan:
- $\operatorname{pmax}$
$=235000 \mathrm{~kg} \quad=235$ ton
- $\mathrm{pu}$
- Mutu baja tulang
$=\sum \mathrm{v}=245071 \mathrm{~kg}=245,071 \mathrm{ton}$
- Mutu beton (fc)
$=400 \mathrm{MPa}$
- $\varnothing$ spiral
$=30 \mathrm{MPa}$
- D tulang pokok
$=10 \mathrm{~mm}$
- Tebal selimut
$=25 \mathrm{~mm}$
- D tiang
$=75 \mathrm{~mm}$
$=100 \mathrm{~cm}=1000 \mathrm{~mm}$

Adapun $\mathrm{e}=6,5 \mathrm{~mm}<\mathrm{eb}=257,668 \mathrm{~mm}$, sehingga penentuan kehancuran dan eksentrisitas oleh gaya tekan.

Sesuai perhitungan di atas, perencanaan penampang kolom sudah terpenuhi syarat, sehingga ukuran tulangan dan tiang bisa dipakai. Berdasarkan hitungan penulangan pondasi tiang sumuran, tulangan yang dipakai adalah untuk spiral: $\varnothing 10-50$; untuk pokok: 28 D 25. 


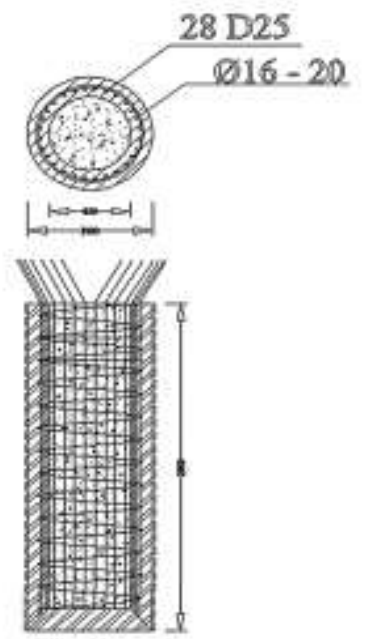

Gambar 5. Penulangan tiang sumuran

\section{Kesimpulan}

Beban yang harus ditahan < daya dukung pondasi sumuran. Sehingga pondasi sumuran sesaui penggunaan. Tipe 1 "diketahui $\mathrm{Qa}=313,323$ ton $>\mathrm{Pu}=245,071$ ton", tipe 2 diketahui $\mathrm{Qa}=$ 200,363 ton $>\mathrm{Pu}=125,424$ ton, dan tipe 3 diketahui $\mathrm{Qa}=200,735$ ton $>\mathrm{Pu}=19,296$ ton. Terhadap hasil perhitungan penulangan pile cap pada tulangan tarik memakai tulangan D19 200 dan tulangan tekan memakai tulangan D10 - 250, adapun sumuran memakai tulangan spiral Ø $10-50$ dan tulangan pokok 28 D 25. Tipe pondasi 1 dipakai pada penulangan pondasi sumuran. Sesuai dengan hasil analisa perhitungan dipakai tulangan pokok, diameter pondasi, jarak antar tulangan pokok, diameter tulangan spiral, jumlah tulangan pokok dan jarak tulangan spiral satu tipe yakni diameter 1 meter. Pada tulangan spiral $\varnothing 10-50$ dan tulangan pokok $28 \mathrm{D} 25$. Hal tersebut disebabkan pendistribusian tegangan beban yang harus ditopang tiang sumuran dari hasil perhitungan jika dilakukan perencanaan tulangan dan dimensi sama, sesuai penggunaan.

\section{Referensi}

Badan Standardisasi Nasional. (2015). Spesifikasi Untuk Bangunan Gedung Baja Struktural (SNI 1729-2015).

Badan Standardisasi Nasional. (2013). Persyaratann Beton Struktural untuk Bangunan Gedung (SNI 2847-2013).

Badan Standardisasi Nasional. (2012). Tata Cara Perencanaan Ketahanan Gempa Untuk Struktur Bangunan Gedung Dan Non Gedung (SNI 1726-2016).

Bowles, L. E. (1996). Foundation analysis and design. McGraw-hill.

Direktorat Penyelidikan Masalah Bangunan. (1983). Peraturan Pembebanan Indonesia Untuk Gedung $(P P I U G)$. Bandung: Yayasan Lembaga Penyelidikan Masalah Bangunan.

Hardiyatmo, H. C. (1996). Teknik Fondasi 1. Gramedia Pustaka Utama.

Hardiyatmo, H. C. (2008). Teknik Fondasi II. Yogyakarta: Beta Offset.

Nasution, A. (2009). Analisis dan Desain Struktur Beton Bertulang. Bandung: Penerbit ITB.

Nawy, E. G., Surjaman, T., \& Suryoatmono, B. (1990). Beton Bertulang: Suatu Pendekatan Dasar. Bandung: PT. Eresco.

Pamungkas, A., \& Erni, H. (2013). Desain Pondasi Tahan Gempa. Yogyakarta: Andy Offset.

Rahardjo, P. P. (2005). Manual Pondasi Tiang Edisi 3. Bandung: Publikasi GEC, Universitas Katolik Parahyangan.

Sardjono, H. S. (1991). Pondasi Tiang Pancang jilid 1-2. Surabaya: Sinar Wijaya.

Tomlinson, M., \& Woodward, J. (2014). Pile design and construction practice. CRC Press. 


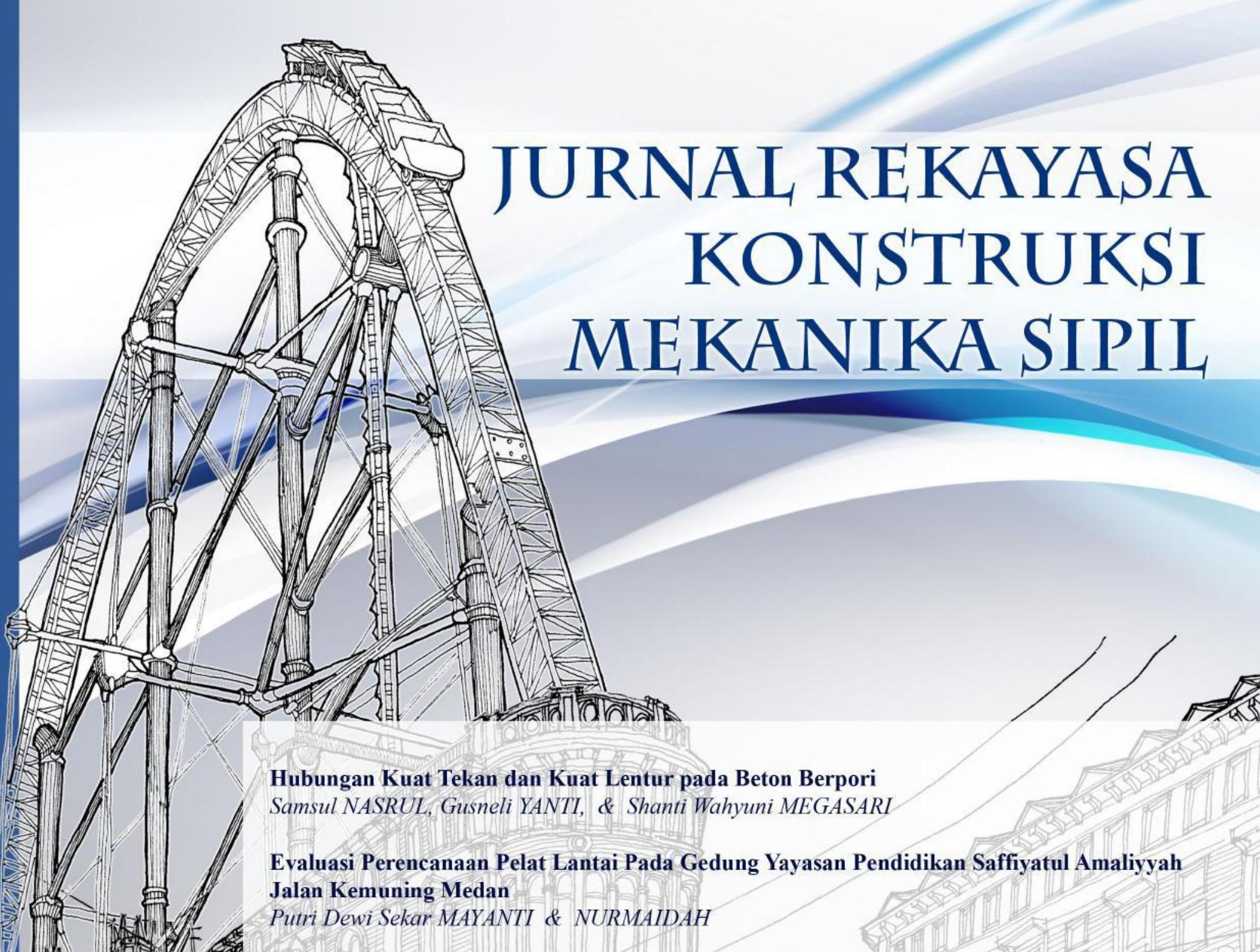

Studi Perencanaan Pondasi Sumuran Pada Pembangunan Gedung Bertingkat Tinggi (Perbandingan Antara Pondasi Tiang Pancang dan Pondasi Sumuran)

Soaloon Prima SIMALANGO, Agus PURBA, \& Kasimir SAWITO

Keinginan Menggunakan Angkot di kota Medan dengan Peningkatan Layanan Informasi Reynaldo SIAHAAN \& TOMmy Iswan LASE

Pengendalian Biaya dan Waktu dengan Metode Earned Value (Studi Kasus: Rancang dan Bangun Sistem Penyediaan Air Minum Kota Dumai 450 LPD Tahap 1A)

Edhi Pandu SUKMONO, ZAINURI, \& Widya APRIANI

Estimasi Besarnya Biaya Proyek Akibat terjadinya Rework pada Pekerjaan Finishing Ni Kadek Sri Ebtha YUNI

Pelaksanaan Manajemen Keselamatan Dan Kesehatan Kerja (SMK3) Pada Proyek Kontruksi, Studi Kasus di Kota Jakarta

Edison Hatoguan MANURUNG, Kasimir SAWITO, \& Isni Rizky YUSHADI

Fakultas Teknik Universitas Katolik Santo Thomas JI. Setia Budi No. 479-F Tanjung Sari, Medan 


\section{Jurnal Rekayasa Konstruksi Mekanika Sipil (JRKMS)}

Jurnal Rekayasa Konstruksi Mekanika Sipil (JRKMS) diterbitkan oleh Fakultas Teknik Universitas Katolik Santo Thomas. JRKMS berisi artikel-artikel ilmiah yang meliputi kajian di bidang Teknik khususnya Teknik Sipil seperti Matematika teknik, Mekanika teknik, Analisis struktur, Konstruksi baja, Konstruksi beton, Konstruksi kayu, Konstruksi gelas, Mekanika tanah, Teknik Pondasi, Hidrologi, Hidrolika, Bangunan air, Manajemen konstruksi, Dinamika Struktur, Earthquake Engineering, Informatika, Ilmu Ukur Tanah, Struktur bangunan sipil, Rekayasa Jalan Raya, serta penelitian-penelitian lain yang terkait dengan bidang-bidang tersebut.

Terbit dalam 2 (dua) kali setahun yaitu pada bulan April dan September

\section{Penasihat :}

Prof. Dr. Drs. Sihol Situngkir, MBA. (Rektor Universitas Katolik Santo Thomas)

\section{Ketua Penyunting (Editor in Chief) :}

Ir. Oloan Sitohang, M.T. (Universitas Katolik Santo Thomas)

Manajer Jurnal (Managing Editor):

Reynaldo, S.T., M.Eng. (Universitas Katolik Santo Thomas)

\section{Anggota Penyunting (Editorial Board):}

Medis Sejahtera Surbakti, S.T, M.T., Ph.D. (Universitas Sumatera Utara)

Dr. Janner Simarmata (Universitas Negri Medan)

Ir. Martius Ginting, M.T. (Universitas Katolik Santo Thomas)

Samsuardi Batubara, S.T., M.T. (Universitas Katolik Santo Thomas)

\section{Mitra Bestari (Peer Reviewer):}

Dr.Eng. Aleksander Purba (Universitas Lampung, Indonesia)

Ir. Binsar Silitonga, M.T. (Universitas Katolik Santo Thomas, Indonesia)

Ir. Charles Sitindaon, M.T. (Universitas Katolik Santo Thomas, Indonesia)

Dr. Erica Elice Uy (De La Salle University, Philippines)

Dr. Harijanto Setiawan (Universitas Atma Jaya Yogyakarta, Indonesia)

Dr.Eng. Jeffry Swingly Frans Sumarauw (Universitas Sam Ratulangi, Indonesia)

Prof. Dr-Ing. Johannes Tarigan (Universitas Sumatera Utara, Indonesia)

Linda Prasetyorini (Universitas Brawijaya, Malang, Indonesia)

Dr.Eng. Mia Wimala (Universitas Katolik Parahyangan, Indonesia)

Dr.Eng. Minson Simatupang (Universitas Halu Oleo, Indonesia)

Dr. Mochamad Raditya Pradana (Keppel Marine and Deepwater Technology, Singapura)

Dr. Senot Sangadji (Universitas Sebelas Maret, Indonesia)

Ir. Simon Dertha, M.T. (Universitas Katolik Santo Thomas, Indonesia)

Dr. Thi Nguyên Cao (Tien Giang University, Viet Nam)

\section{Ilustrator Sampul:}

Yulianto, ST., M.Eng

\section{Penerbit \& Alamat Redaksi:}

Fakultas Teknik Universitas Katolik Santo Thomas

J1. Setiabudi No. 479-F Tanjung Sari, Medan 20132

Telp. (061) 8210161 Fax : (061) 8213269

email : unika.sipil@yahoo.com 


\section{Konten}

REKAYASA STRUKTUR

hal.

Hubungan Kuat Tekan dan Kuat Lentur pada Beton Berpori

Samsul NASRUL, Gusneli YANTI, \& Shanti Wahyuni MEGASARI

Evaluasi Perencanaan Pelat Lantai Pada Gedung Yayasan Pendidikan

Saffiyatul Amaliyyah Jalan Kemuning Medan

Putri Dewi Sekar MAYANTI \& NURMAIDAH

REKAYASA GEOTEKNIK

Studi Perencanaan Pondasi Sumuran Pada Pembangunan Gedung

Bertingkat Tinggi (Perbandingan Antara Pondasi Tiang Pancang dan

Pondasi Sumuran)

Soaloon Prima SIMALANGO, Agus PURBA, \& Kasimir SAWITO

REKAYASA TRANSPORTASI

Keinginan Menggunakan Angkot di kota Medan dengan Peningkatan

Layanan Informasi

Reynaldo SIAHAAN \& Tommy Iswan LASE

MANAJEMEN KONSTRUKSI

Pengendalian Biaya dan Waktu dengan Metode Earned Value (Studi Kasus:

Rancang dan Bangun Sistem Penyediaan Air Minum Kota Dumai 450 LPD

Tahap 1A)

Edhi Pandu SUKMONO, ZAINURI, \& Widya APRIANI

Estimasi Besarnya Biaya Proyek Akibat terjadinya Rework pada Pekerjaan

Finishing

Ni Kadek Sri Ebtha YUNI

Keselamatan dan Kesehatan KerJa

Pelaksanaan Manajemen Keselamatan Dan Kesehatan Kerja (SMK3) Pada

Edison Hatoguan MANURUNG, Kasimir SAWITO, \& Isni Rizky YUSHADI 


\section{Pengantar Redaksi}

Puji dan syukur kami sampaikan kepada Tuhan Yang Maha Esa karena atas rahmatNya kami dapat menyelesaikan penerbitan Jurnal Rekayasa Konstruksi Mekanika Sipil (JRKMS) Volume 4 Nomor 1, di bulan Mei tahun 2021 ini. Jurnal ini fokus pada beragam subbidang dalam Teknik Sipil antara lain Rekayasa Struktur, Rekayasa Geoteknik, Rekayasa Transportasi, Teknik Sumber Daya Air, dan Manajemen Konstruksi. Namun, tidak menutup kesempatan bagi subbidang lainnya yang berkaitan dengan keilmuan Teknik Sipil.

Memasuki tahun ke-2 dalam kondisi pandemi COVID-19, keterbatasan dalam melakukan penelitian tidak menurunkan produktivitas kita dalam meneliti serta mempublikasikannya. Penelitian tetap harus dijalankan dan produktivitas peneliti di Indonesia masih harus terus berkembang. Dalam edisi ini, terdapat 7 artikel yang terdiri atas dua (2) artikel dalam topik Rekayasa Struktur, satu (1) artikel dalam topik Rekayasa geoteknik, satu (1) artikel dalam topik Rekayasa Transportasi, dua (2) artikel dalam topik Manajemen Konstruksi, dan satu (1) artikel dalam topik Keselamatan dan Kesehatan Kerja (K3). Redaksi memiliki kerinduan agar semakin banyak peneliti yang menerbitkan karya berkualitasnya di JRKMS untuk mendukung pengembangan wawasan dalam dunia teknik sipil. Apresiasi kami berikan kepada penulis yang tulisannya diterbitkan pada Volume 04 Nomor 01 Mei 2021 ini karena telah menginvestasikan waktu dalam menuangkan ide dan merespon masukan dari mitra bestari hingga karyanya siap untuk diterbitkan.

Sebagai penutup, yang menjadi harapan tim editorial adalah semoga jurnal ini dapat menjadi media ilmiah yang berguna bagi civitas akademika, dan perkembangan ilmu pengetahuan serta penelitian di bidang ilmu ketekniksipilan di Indonesia. Salam hangat. Salam sehat.

Mei 2021

Tim Editorial 
JURNAL REKAYASA KONSTRUKSI MEKANIKA SIPIL | Volume 4 | Nomor 1 | Mei 2021| Jurnal IImiahTeknik Sipil Fakultas Teknik Universitas Katolik Santo Thomas ejournal.ust.ac.id/index.php/JRKMS

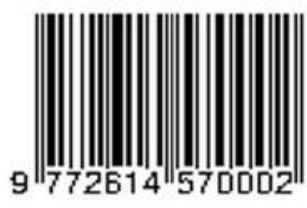

Google RaARUDA ISJDNeo : : neliti Donesearch PBASE 